\title{
The Category of Tense as a Universal Concept (Linguistic Overview)
}

\section{Rena Huseynaga Huseynova ${ }^{1}$}

\author{
${ }^{1}$ Azerbaijan Medicine University \\ 23 Bakikhanov Street, Baku, 370022, Azerbaijan
}

DOI: $10.22178 /$ pos.69-4

LCC Subject Category:

PE1001-1693

Received 16.03.2021

Accepted 26.04.2021

Published online 30.04.2021

Corresponding Author:

rena.huseynova.70@inbox.ru

\author{
(C) 2021 The Author. This article \\ is licensed under a Creative \\ Commons Attribution 4.0 \\ License @ (1)
}

\begin{abstract}
The article considers the category of tense as a universal phenomenon from the point of view of linguistics. The tense category belongs to the number of universal concepts that play a crucial role in modern science, in all its disciplinary complexes: both natural, social and humanitarian. Not a single sphere of human activity is complete without contact with the reality of time. Everything that moves, changes, lives, acts, and thinks is spread through time in one form or another. But despite the obviousness of time as an objective phenomenon has given to us in sensations, which is undoubtedly confirmed by our individual experience, the conceptual understanding of time both in the history of philosophy and science gives rise to many different, sometimes opposite approaches and results. Analysis of the tense category is one of the most actively developed topics in Russian and foreign science. The problem of time interpretation has attracted researchers for its inexhaustibility and versatility. It will never lose its relevance since the concept of time, along with the concepts of space and motion, is one of the essential categories of the knowledge theory. The interpretation of time is inextricably linked with the most fundamental ideas of a person about reality - with the interpretation of being, the meaning of life, all human activity - both cognitive and practical.
\end{abstract}

Keywords: time; tense category; human consciousness; perception; grammatical.

\section{INTRODUCTION}

The tense category is universal and multifaceted. The time problem began to be dealt with first in natural science, physics, philosophy, and then in other sciences: culturology, psychology, linguistics, entolinguistics, etc. Within physics and philosophy, time is presented as a primary category of the scientific world picture.

Researchers have identified different models of time conceptualization in different cultures and languages. So, since ancient times, two main coexistence models coexist in the human mind - "cyclical" time and "linear" time. The cyclical idea of time as a rotation in a circle, as a sequence of events of the same type, was characteristic of archaic civilizations [14, p. 133]. It is associated by origin with the cyclical phenomena of nature. And the development of ideas about the linear movement of time is associated with the formation of historical consciousness [14, p. 100-101]. Linear time is presented as a straight line without beginning and end, dissected by a "presence point" into the past, the future and the present that connects them [13, p. 52]. Scientists note that within the framework of the WLP, cyclic and linear time complement each other. Cyclic time perception is reflected in the lexical composition, linear time in the grammatical system [1, p. 6]. Time is cyclical (mythological), repeating and linear, unidirectional, with a beginning and an end [8, p. 316]. In an individual's real life, you can neither "stop the moment" nor go back.

The philosophical interpretation of time proceeds from the differentiation of 1) existential time as a form of authentic being and 2) time reflected in culture, society and individual consciousness, i. e. as an independent parameter of the spiritual life of society and the individual. This second form is known as perceptual time. Perceptual time plays a unique role among the cognitive structures and processes involved in the perception of the real world. With its help, the real world is transformed into a "projected world" accessible to human consciousness. Therefore, perceptual time contains a subjective element. It is associated primarily with our "sense of time", the sense of the past, present and future, associated with the change of experiences, thoughts, memories, etc. [7, p. 1006]. A person's perception of events in time gives him the concept of time or conceptual (perceptual) time. Such a mental transformation converts the 
diffuseness of real-time as an object of naming into a discrete value. The relations that characterize the properties of objective and conceptual time are reflected in the language. However, "less discreteness and greater diffuseness of naming objects give rise to a weakening of the dependence of the semantic system of the language on the system of the real world" [5, p. 143]. However, conceptual time also has features that are not characteristic of objective time, for example, cyclicality. According to dialectical materialism, our sensations are images, copies of things that exist objectively, independently of a person. Perceptual time, therefore, reflects objectively existing, actual time. Human ideas about time and space have undoubtedly relative character, but the absolute truth is formed from these relative ideas - these relative ideas in their development approach absolute truths.

Existentialist philosophers (M. Heidegger, K. Jaspers, J. P. Sartre, A. Camus, G. Marcel) made a significant contribution to time study. They considered this category, not from a physical but a spiritual, moral, aesthetic point of view. Living in time is an existential slogan that can solve many problems. To live in time means to live not only in one's own becoming with its unpredictable variability of desires and moods but also in a changing environment of desires and moods. According to M. Heidegger, time should be considered as the essential characteristic of being (in existentialism, the problem of time becomes one of the central ones). Affirming the unity of time and being, $M$. Heidegger proves that nothing that exists except man knows about its finitude, which means that only man knows temporality.

Moreover, time is inextricably linked not just with being but with a human being. The essence can be revealed only in its relation to a person [2, p. 327]. Perceptual (psychological) time is associated with the perception and experience of time by the individual: time "runs", then "slows down", which depends on certain specific situations. This is a subjective sense of time, and it only generally corresponds to real physical time. Psychological time includes assessments of simultaneity, sequence, duration, speed of various life events, their belonging to the present, remoteness in the past and the future, experiences of compression and extension, discontinuity and continuity, limitation, and infinity time. In many ways, psychological time is determined by physical time.

\section{RESULTS AND DISCUSSION}

In linguistics, time is understood as an anthropocentric, subjective category since a person perceives the world through the prism of his sensations. The idea that time is related to the speaker's view of the world first appeared in the linguistic relativity theory by B. L. Whorf.

Researcher A. M. Mostepanenko expresses that no phenomenon or process is possible outside space and time [6, p. 21]. The scientist distinguishes actual and perceptual (subjective) time. Real-time belongs to the sphere of the objective external world. It is associated with the order of changing the states of natural objects and phenomena. Perceptual time reflects the perception of the external world by an individual, "our sense of the present, past and future is connected with perceptual time" [6, p. 4]. According to the researcher, perceptual time does not always coincide with realtime, although it reflects it. Real-time has two types of properties: topological (temporal order, sequence of events; qualitative aspect of time) and metric (temporal extent, duration; quantitative aspect of time) [6, p. 66-68].

Since human consciousness is a perceiving system that projects its properties onto the object itself, that is, over time, we call these concepts anthropological concepts. Contemporary linguists also indicate the relativity of perception of time and space, linking this feature with anthropocentricity $[11$, p. 30]. Due to the development of his consciousness, a person that time acquires an additional property - directed movement. From the direction of the anthropological concepts of time, it is divided into the present, the past and the future. In different concepts, the direction of movement is different, and opinions about which time plans are actual and do not differ. The order present - past - future, which expresses the qualitative aspect of the temporal sequence, serves as a definite expression of the structure being. "Time (in philosophy), an irreversible, unique sequence, characterized by duration" [9, p. 129].

Based on physical time, whose properties are described in cosmological concepts, a person creates his own internal time. He changes the structure of the properties of physical time, imposing the limiting factors, born of consciousness and perception, on these properties. "A person lives and functions not only in the space and time of the real physical, social world but also in his personal individual space and time, dependent on him, 
conditioned by him, impossible without him" [10, p. 119].

The time transmitted using language is a reflection of real-time through perceptual time. And its organization is determined by the laws of the natural world and at the same time possesses the originality generated by the peculiarities of the mechanism for reflecting the time in the language.

The real-time category can be expressed by lexical, derivational and grammatical means. The means of representing time exist at the grammatical and lexical levels. At the lexical level, time is represented by nouns with a temporal meaning, for example: second, minute, hour, day, morning, day, evening, night, spring, summer, autumn, winter, time, century, year, epoch, etc. At the morphological level is represented by forms of verbs with the meaning of tense, for example: comes, comes, comes; lives, has lived, will live, etc. At the syntactic level, time is conveyed by temporal syntactic constructions; for example, An exam is in progress; Time has passed; Years will fly by; The moment of glory has come, Time is money, etc. Time is expressed in language and, consequently, in culture, too. This category is associated with the concept of a world linguistic picture (WLP), which is traditionally interpreted as "a pattern of perception of reality, fixed in the language, specific for a given linguistic community" [4, p. 9]. In other words, time is "a repository of events, another name for life" [4, p. 55]. Indeed, a person's life consists of the following elements of time: day, week, month; childhood, adolescence, old age; birth, moment, year, eternity, death, etc., by which one can judge that time is measurable and discrete. Word formation means playing an important role in displaying the time category in a language.

Expressed by linguistic means, temporary relations exist objectively and independently of the speakers. They are nevertheless directly related to the participants and the communication situation. Unlike space, which is objective and static, time is eventful. Therefore, an essential feature of language time is it's situational. Nevertheless, the temporary deixis of speaking is inevitably selfish since it is always determined by the speaker himself, who pronounces "now", i.e., the starting point in temporal deixis is "I" represented by the speaker.

On the other hand, the use of forms of linguistic time is objectively conditioned, and the speaker, choosing the appropriate units, acts under the compulsion of objective reality. The starting point, which serves as the speech moment for the speaker, is understood not as the real-time of the act of verbal communication, but as a kind of "grammatical idealization", reflecting this time, as a "communicative model element" [15, p. 47]. The speech moment is constantly present in the speaker's consciousness when he perceives and realizes the actual time, acting as a criterion for identifying the temporal spheres "present", "past" and "future" and creating potential sema in temporal forms. Since the semantics of linguistic forms reflect not only and not so much the substantial properties of physical time, but rather the relationship of a person to real-time. The linguistic time is a reflected form of time and is reflected; it can acquire relative independence from the actual temporal characteristics of the described events.

Grammatical time in English is closely related to the category of temporality. Temporality is a complex concept, more fully developed in the Englishlanguage scientific and reference literature. So, the English noun temporality and the adjective "temporal" / "temporary" are similar to the Azerbaijani definition - "temporary character". In English, the concept of temporality in meaning and etymology is closer to the word "temporal" than to "time". Considering the etymology of the grammatical concept "tense" in English, we conclude that grammatical tense is an integral part of the universal category of time and is directly related to the expression of a person's ideas about the structure of the world, the essence of being, as well as the expression of his ethical views. Language "tense" in English, in contrast to the universal concept "time", captures the specific features and unique historical experience of the English language. Its study helps to identify the national features of the worldview of these people.

The language grammar fixes the genetic memory of the time category, transforms it into an individual-time continuum, perceived as a subjectively experienced time. It is reflected in the linguistic consciousness of an ethnos in the form of a national character. The grammatical concept "tense" encodes a person's subconscious reaction to the surrounding reality, transmitting the mechanism of transformation of temporal experience and sense of time into the temporal semantics of language units, which is fixed by the "ethnic dissimilarity" of the temporal models of the Russian and English languages [12, p. 410]. 
In the representation of grammatical tense in the English language consciousness, a considerable proportion belongs to temporality. Underlying based on grammatical concept, the sense of time is comparable within the framework of linguoculturological analysis with the grammatical image of time, presented not so much as a visual picture, but as a consciousness category, as a model of reality events perceived by a person at a "presence point". On the one hand, grammatical time is a reflection of real-time relations in the human mind. On the other hand, it encodes a personal sense of time, an estimate of the duration of time segments that do not necessarily correspond to objective time. In our opinion, grammatical time is the basis of perceptual or emotive time, which is separated from the real in the process of experiencing objective time and memories, in an internal monologue, in imagination, in dreams.

\section{CONCLUSION}

Summing up, it should be emphasized that the sense of time acquires its specific refraction in the grammar of languages since grammar is a program and a guide for a person's mental activity. However, the idea of time among different peoples is reflected not only in their natural language but also in the grammatical concept "time". The grammatical concept "time" captures differences in the perception of the current time (past-present-future) in ethnic cultures. It becomes part of their perception of the world, which, in turn, affects the formation of national stereotypical behaviour models.

\section{REFERENCES}

1. Ahmedova, Z.M. (2019). Koncept vremeni v kognitivnom aspekte v anglijskom jazyke [The concept of time in the cognitive aspect in English]. Vestnik Volzhskogo universiteta imeni V.N. Tatishheva, 1(1), 5-12 (in Russian).

2. Hajdegger, M. (1993). Vremja i bytie [Time and Being]. Moscow: Respublika (in Russian).

3. Jakovleva, E. S. (1994). Fragmenty russkoj jazykovoj kartiny mira (modeli prostranstva, vremeni $i$ vosprijatija) [Fragments of the Russian linguistic picture of the world (models of space, time and perception)]. Moscow: Gnozis (in Russian).

4. Jakovleva, E. S. (1996). K opisaniju russkoj jazykovoj kartiny mira [To the description of the Russian language picture of the world]. Russkij jazyk za rubezhom, 1-3, 47-56 (in Russian).

5. Martinovich, G. A. (1990). Tipy verbal'nyh svjazej i otnoshenij v associativnom pole [Types of verbal connections and relationships in the associative field]. Voprosy psihologii, 2, 143-146 (in Russian).

6. Mostepanenko, A. M. (1969). Problema universal'nosti osnovnyh svojstv prostranstva i vremeni [The problem of universality of the basic properties of space and time]. Leningrad: Nauka (in Russian).

7. Nasyrova, Je. A. (2012). Logiko-filosofskaja interpretacija i lingvisticheskij aspekt kategorii vremeni [Logical and philosophical interpretation and linguistic aspect of the category of time.]. Vestnik Bashkirskogo universiteta, 17(2), 1005-1008 (in Russian).

8. Nil'sen, E. A. (2014). Osnovnye tendencii razvitija metafor vremeni v anglijskom jazyke [The main trends in the development of time metaphors in the English language]. Kognitivnye issledovanija jazyka. Kognitivnoe var'irovanie v jazykovoj interpretacii mira, 19, 315-324 (in Russian).

9. Osipov, Yu. S. (Ed.). (2001). Novaja illjustrirovannaja jenciklopedija [New Illustrated Encyclopedia] (Vol. 4). Moscow: Bol'shaja rossijskaja jenciklopedija (in Russian).

10. Potaenko, N. A. (1997). Vremja v jazyke (opyt kompleksnogo opisanija) [Time in language (experience of complex description)]. In Logicheskij analiz jazyka. Jazyk i vremja (p. 113-121). Moscow: Indrik (in Russian).

11. Pozdnikova, E. U. (2019). The models of time in comtemporary humanities. Chelovek. Kul'tura. Obrazovanie, 1(31), 27-33. 
12. Razorenov, D.A. (2010). Grammaticheskoe vremja kak chast' anglojazychnoj kartiny mira [Grammatical time as part of the English-speaking picture of the world]. Izvestija TulGu, 2, 407412 (in Russian).

13. Stepanov, Ju. S. (2004). Konstanty: slovar' russkoj kul'tury: opyt issledovanija [Constants: Dictionary of Russian Culture: Research Experience]. Moscow: Akademicheskij Proekt (in Russian).

14. Tumanova, A. B., Pavlova, T. V. \& Zueva, N. Ju. (2019). Kategorija vremeni v sovremennoj nauke: analiz i interpretacija [The category of time in modern science: analysis and interpretation]. Neophilology, 5(18), 131-138 (in Russian).

15. Veden'kova, M. S. (1982). Vremennaja differenciacija i vremennaja determinirovannost' glagol'nogo dejstvija [Temporal differentiation and temporal determinism of verb action]. In Glagol v germanskih i romanskih jazykah (pp. 46-57). Dnepropetrovsk: n. d. (in Russian). 